\title{
Relationships of Otolith Dimension with Body Length of European Eel Anguilla anguilla (Linnaeus, 1758) from Adriatic catchment of Montenegro
}

\author{
Tamara KANJUH ${ }^{1}$, Danilo MRDAK ${ }^{1}$, Marina PIRIA ${ }^{2}$, Tea TOMLJANOVIĆ ${ }^{2}$, \\ Aleksandar JOKSIMOVIĆ ${ }^{3}$, Trajče TALEVSKI ${ }^{4}$ and Dragana MILOŠEVIĆ ${ }^{1 *}$ \\ ${ }^{1}$ University of Montenegro, Faculty of Natural Sciences and Mathematics, \\ Department of Biology, G. Washington Street, P. box 5455, 81000 Podgorica, Montenegro \\ ${ }^{2}$ University of Zagreb, Faculty of Agriculture, Department of Fisheries, Beekeeping, Game \\ Management and Special Zoology, Svetošimunska 25, 10000 Zagreb, Croatia \\ ${ }^{3}$ Institute of Marine Biology, University of Montenegro, Dobrota b.b., 85330 Kotor, Montenegro \\ ${ }^{4}$ Hidrobiological Institute, Department of Cyprinid Fauna, Ohrid \\ *Corresponding author, e-mail: draganam25@gmail.com
}

\begin{abstract}
This study examined the relationship between the sagittal otolith morphometric variables (length, height and weight) and body growth of the European eel. Eels that were studied ranged in total length from 11.2 to $79.5 \mathrm{~cm}$. The relationships between the sagittal otolith variables and fish somatic growth were described with a non-linear function. The resulting coefficients of determination $\left(r^{2}\right)$ ranged from 0.782 to 0.914 . The variable most strongly related to fish size was found to be the sagittal otolith length (OL) with $91.4 \%$ of the variability. The results of this study provide the first comprehensive data regarding the relationship between the sagittal otolith morphometric variables with body length of Anguilla anguilla.
\end{abstract}

Key words: Anguilla anguilla, Adriatic Sea, River Bojana, otolith morphometry, somatic growth

\section{INTRODUCTION}

The European eel Anguilla anguilla (LINNAEUS, 1758) is a catadromous fish species with a complex life history. She begins life in the Sargasso See of the western North Atlantic, but the continental distribution (as resident yellow eels) encompasses the coastal and inland waters of Europe and North Africa (DEKKER, 2003; $\mathrm{TESCH}, 2003)$. It is also found in Turkish rivers and streams draining into Mediterranean Sea,
Aegean Sea and part of the Black Sea (KÜÇÜK et al., 2005; YALÇIN-ÖZDILEK et al, 2006; YALÇINÖZDILEK \& SOLAK, 2007). Towards the end of the lifecycle, yellow eels metamorphose into migratory silver eels, which return to the Sargasso Sea to reproduce and die (TESCH, 2003). European eel panmixia theory is generally accepted, even though it has been debated for long time (WIRTH \& BERNATCHES, 2001; BIANCHINI et al., 2009). The species was added to the IUCN Red List of Threatened Species as critically endangered (FREYHOF \& KOTTELAT, 2010), and its stock is 
characterized as outside safe biological limits (ICES, 1999).

Otoliths are structures located in the inner ear cavity of all teleost fish. By using the relationship between fish length and otolith dimensions it is possible to not only identify fish species and fish stock, but also to estimate characteristics such as fish size, age, prey size (from stomach samples and analysis of digestive tract content) and feeding habits (DEHGHANI $e t$ al., 2015). PANFILI et al. (1990) and CAPOCCIONI et al. (2011) reported two different types of sagittae of eel, depending on the width of the growth rings, which they called "brackish water type" and "freshwater type"otolith, respectively.

In spite of the high commercial importance of the species, its biology and ecology have been poorly investigated in Montenegro. Recent studies of these species have been related to lengthweight relationship and condition factor (MILOŠEVIĆ \& MRDAK, 2016; PIRIA et al., 2016). Till now there were no attempts toward eel assessment in any term (immigration, migration, fishery etc.) and no management units established yet. Also, no yellow eel abundance surveys or silver eel escapements surveys have ever been made in Montenegro. Researches on the relationship between otolith morphometry of European eel (silver phase) are practically absent, and besides the lack of necessary reference lists, no estimates were available in the international scientific literature; including a lack of records in the electronic data bank, FishBase (FROESE \& PAULY, 2016).

Therefore, the aim of the present study was to describe for the first time the relationship between otolith growth and somatic growth of European eel from the Adriatic catchment of Montenegro.

\section{MATERIAL AND METHODS}

Fish were collected from three different habitats in Montenegro (Lake Skadar, River Bojana and River Sutorina) on a monthly basis between November 2014 and June 2015. The specimens were caught using electric gear (Ultrasonic Inverter DC-12V LJ-4025NP). Fish were mea- sured to the nearest $0.1 \mathrm{~cm}$ in relation to total length (TL). A total of 60 specimens were captured during the sampling period. The right sagittal otolith from each fish was removed, cleaned and stored dry in properly labeled envelopes. The otolith weight $(\mathrm{OW})$ was recorded to the nearest $0,1 \mathrm{mg}$. Otolith length (OL), defined as the greatest distance between anterior and posterior edge, and otolith height $(\mathrm{OH})$, defined as the greatest distance from dorsal to ventral edge, were measured to the nearest $0.001 \mathrm{~mm}$ using a Carl Zeiss Axio Scope A1. The relationships between otolith measurements (length, height and weight) and fish size were determined by a power equation $\mathrm{Y}=a \mathrm{X}^{b}$, where $\mathrm{Y}$ is otolith dimension, $\mathrm{X}$ is fish length, $a$ is the intercept, and $b$ is the slope. The parameters $a$ and $b$ were estimated through a linear regression analysis based on logarithms, $\log \mathrm{Y}=\log a+b \log \mathrm{X}$. The t-test was used to compare the slopes with a value corresponding to isometry (ZAR, 1999). The strength of each relationship was evaluated from the determination coefficient $\left(r^{2}\right)$. The statistical procedure was completed using SPSS Statistics 20 and STATISTICA 7.0.

\section{RESULTS}

The descriptive statistics of fish and otolith variables are given in Table 1. All regresions were highly significant $(\mathrm{P}<0.001)$. The analysis of otolith morphometric parameters versus total fish lenght indicated the regression models explained more than $80 \%$ of variance of OL and $\mathrm{OH}$ (Table 2, Fig. 1). The coefficients of determination $\left(r^{2}\right)$ ranged from 0.782-0.914 (Fig. 1). The variable most strongly related to fish size was the otolith length (OL) with $91.4 \%$ of the

Table 1. The descriptive statistics of fish total length (TL, $\mathrm{cm})$, otolith length $(\mathrm{OL}, \mathrm{mm})$, otolith height $(\mathrm{OH}, \mathrm{mm})$ and otolith weight (OW, mg) of European eel from the Adriatic catchment of Montenegro

\begin{tabular}{cccc}
\hline Measure & N & Mean \pm SD & Min - Max \\
\hline TL & 60 & $42.9 \pm 14.0$ & $11.2-79.5$ \\
OL & 60 & $2.67 \pm 0.73$ & $1.18-4.84$ \\
OH & 60 & $1.79 \pm 0.38$ & $0.88-2.58$ \\
OW & 60 & $4.7 \pm 3.0$ & $0.1-16.2$ \\
\hline
\end{tabular}


Table 2. Regression parameters of the relationship between otolith dimensions and the total body lenght of European eel in Montenegro: TL-total body length, OL-otolith length, OH-otolith height, OW-otolith weight, n-number of samples, $a$ and b-regression coefficients, standard error SE, r2-correlation coefficient, p-level of significance

\begin{tabular}{cccccccc}
\hline Relationship & $\mathbf{n}$ & $\boldsymbol{a}$ & $\mathbf{S E}(\boldsymbol{a})$ & $\boldsymbol{b}$ & $\mathbf{S E}(\boldsymbol{b})$ & $\boldsymbol{r}^{\mathbf{2}}$ & $\boldsymbol{p}$ \\
\hline OL / TL & 60 & 0.132 & 0.047 & 0.791 & 0.056 & 0.914 & $<0.001$ \\
$\mathbf{\text { OH } / \text { TL }}$ & 60 & 0.170 & 0.048 & 0.621 & 0.047 & 0.880 & $<0.001$ \\
$\mathbf{\text { OW } / \text { TL }}$ & 60 & 0.001 & 0.001 & 2.130 & 0.164 & 0.782 & $<0.001$ \\
\hline
\end{tabular}
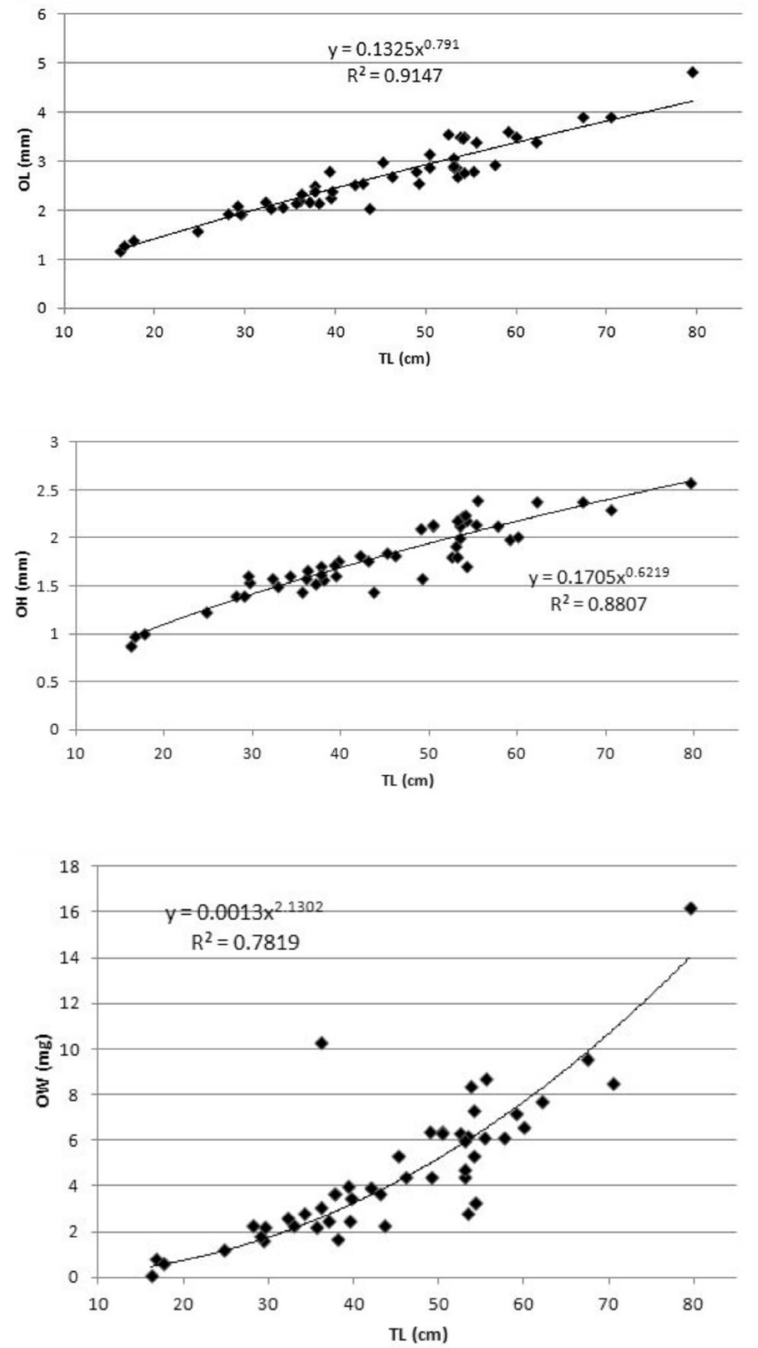

Fig. 1. Relationships of otolith length (OL), height $(\mathrm{OH})$ and weight $(\mathrm{OW})$ versus total length $(T L)$ of European eel from Adriatic catchment of Montenegro variability. The relationships of otolith length, height and weight against total fish length were all shown to have positive allometry (t-test: $\mathrm{OL}-\mathrm{TL}, \mathrm{t}=10.412, \mathrm{P}<0.001 ; \mathrm{OH}-\mathrm{TL}, \mathrm{t}=$ 10.446, $\mathrm{P}<0.001$; OW $-\mathrm{TL}, \mathrm{t}=10.333, \mathrm{P}<$ 0.001 ) indicating that the accretion of otoliths is relatively faster than fish size.

\section{DISCUSSION}

Recent research of relationship between Fulton condition factor and total length on 60 specimens, used for otolith morphometry in this study, indicates that European eels increase with length, proving that Lake Skadar, River Bojana and River Sutorina represent good habitats for eels (PIRIA et al., 2016). This statement was confirmed by isometric growth $(b=2.956)$ of the same specimens obtained in the analysis of their length-weight relationship (MILOŠEVIĆ \& MRDAK, 2016).

In this study, relationships between otolith length, height and weight and fish length were analyzed using a non-linear function (power model). The result of this study indicated that otolith dimensions increase as fish grows in length and therefore, otolith growth can be correlated with fish growth. Otoliths grow by deposition of incremental layers on the surface (MORALES-NIN, 2000). However, otolith length was shown to be more closely related to fish length growth compared to otolith weight, which was found to have a smaller correlation to fish length than either otolith length or weight. In our study, somatic growth and otolith growth were shown to have an approximate overlap of 78 to 
91\%, demonstrating that otolith morphometrics might be good indicators of fish size. CAMPANA (2004) reported that otolith size and shape often changed with the growth of the fish. HOLMGREN \& WICKSTRÖM (2012) found positive correlations between otolith and somatic growth in cultured elvers at $20^{\circ} \mathrm{C}(\mathrm{r}=0.900)$ and $26^{\circ} \mathrm{C}(\mathrm{r}=0.817)$. Such correlation levels have earlier been taken as acceptable criteria for back calculations of previous eel size (ROSI \& VILANI 1980, VOLLESTAD \& JONSSON, 1986, NAGIĆĚ \& BAHNSAWY, 1990). CAPOCCIONI et al. (2011) reported the occurrence of changes in the morphology of the European eel otolith as a function of growth and the different habitat ecology (a river and two brackish water lagoons). According to these results, the shape outline of otolith changes during the ontogenesis, along with the increase in animal size. This modification occurs in a different manner according to the different environments. In the current study, results of the relationship between otolith length and fish length showed the highest positive correlation of the three otolith variables measured $\left(r^{2}=0.914\right)$. Otolith growth is not correlated with somatic growth during anguillid glass eel and elver stage (FUKUDA et al., 2009) but is significantly correlated with the development of pigmentation (POOLE et al., 2004). Hence, otolith shape could further enhance understanding of the post-larval phase of anguillid eels (CAPOCCIONI et al., 2011). YILMAZ et al., (2014), in their research on the correlation of otolith growth and somatic growth of Perca fluviatilis presented the results which showed that the somatic size of the species can be reliably obtained from otolith variables, such as length, height and weight, but should use different equations for females and males. Variables that showed the highest corre- lation with the size of perch were otolith weight (OW) in females $\left(r^{2}=0.874\right)$ and otolith length $(\mathrm{OL})$ in males $\left(r^{2}=0.829\right)$.

The positive allometric relationships of otolith dimensions ( $\mathrm{OL}, \mathrm{OH}$ and $\mathrm{OW}$ ) against fish length implied that the accretion of otolith dimensions is relatively faster than fish size. In contrast, the proportion between the OL and $\mathrm{OH}$ in relation to the length of European perch, Perca fluviatilis Linnaeus, 1758 from Lake Ladik, Turkey, was allometrically negative, indicating that the otolith growth in length and height is relatively slower than the length of the fish (YILMAZ et al., 2014). TL-OW proportions show positive allometry, which is similar to the results presented in this paper.

Further analysis is required and it is suggested that future studies should observe possible differences between the sexes of European eel. The regressions based on this study can be useful for determining fish size which is important factor for fish stock monitoring and management. However, for a better understanding of otolith growth, it is suggested that future studies should concentrate on the relationship between otolith weight and age, and other otolith factors such as thickness, perimeter and shape.

\section{ACKNOWLEDGEMENTS}

The majority of the data for this paper were collected through the bilateral project "Colonization, migration, condition and diet of endangered European eel (Anguilla anguilla) in Mediterranean Croatian and Montenegro ecosystems" between Croatia and Montenegro. The Ministries of Science of the Republic of Croatia and Montenegro financed the project.

\section{REFERENCES}

BIANCHINI, M. L., G.VAGGELLI, R. COSSIO, G. B. PALMEGIANO, F. GAI, L. SOLA, A.ROSSI, R. CORSETTI, D. GIUSTO, G. B. S.GANCITANO \& S. RAGONESE. 2009. European eels from deep Mediterranean waters. American Fisheries Society Symposium 69, 871-874.

CAMPANA, S.E. 2004. Photographic atlas of fish otoliths of the northwest atlantic ocean. NRC Research Press, Ottawa.

CAPOCCIONI, F., C. COSTA, J. AGUZZI, P. M ENESATTI, A. LOMBARTE \& E. CICCOTTI. 2011. Ontogenetic and environmental effects on otolith shape variability in three Mediterranean European eel (Anguilla anguilla, L) 
local stocks. Journal of Experimental Marine Biology and Ecology, 397: 1-7.

DEHGHANI, M., E. KAMRANI, A. SALARPOURI \& E. KAMALI. 2015. Relationship Between Fish Length and Otolith Dimensions (Length, Width) and Otolith Weight of Sardinella sindensis, as Index for Environmental Studies, Persian Gulf, Iran. J Fisheries Livest Prod, $32 \mathrm{pp}$.

DEKKER, W. 2003. On the distribution of the European eel (Anguilla anguilla) and its fisheries. Canadian Journal of Fisheries and Aquatic Sciences, 60: 787-799.

FREYHOFF, J. \& M. KOTTELAT. 2010. Anguilla anguilla. In: IUCN 2011. IUCN Red List of Threatened Species. Version 2011.2. www. iucnredlist.org.

FROESE, R. \& D. PAULY. 2016. FishBase. In: R. Froese \& D. Pauly (Editors). World Wide Web electronic publication. www.fishbase. org, version (10/2016).

FUKUDA, N., M. KUROKI, A. SHINODA, Y. YAMADA, A. OKAMURA, J. AOYAMA, \& K. TSUKAMOTO. 2009. Influence of water temperature and feeding regime on otolith growth in Anguilla japonica glass eel and elvers: does otolith growth cease at low temperature? Journal of Fish Biol. 74 (5): 1915-1933.

HOLMGREN, K \& H. WICKSTRÖM. 2012. Note on otolith growth in elvers, Anguilla anguilla (L.), and the relative otolith size during somatic growth. Arch. Pol. Fish, 20: 207214.

ICES. 1999. Report of the ICES Advisory Committee on Fisheries Management, ICES Cooperative Research Report, International Council for the Exploration of the Sea, pp. 393-405.

KÜÇÜK, F. G., E. GÜMÜS \& Ì. GÜLLE. 2005. The yellow European eel (Anguilla anguilla L., 1766) in Gözlen Creek and assessment of different catching methods. Turkish Journal of Veterinary and Animal Sciences 29: 10611066.

MILOŠEVIĆ, D. \& D. MRDAK. 2016. Length-weight relationship of nine fish species from Skadar Lake (Adriatic catchment area of Montenegro). Journal of Applied Ichthyology, 32: 1331-1333.
MORALES-NIN. 2000. Review of the growth regulation processes of otolith daily increment formation. Fisheries Research, 46: 53-67.

NAGIĆĚ, M. \& M. H. BAHNSAWY. 1990. Age and growth of female eels, Anguilla anguilla, L. in a Polish lake, Jeziorak Lake, Mazurian Lake, District, Poland. Aquacult. Fish. Mgment. 21: 459-470.

PANFILI, J., M. C. XIMÉNÈS \& CHI T. DO. 1990. Age determination of eels in the French Mediterranean lagoons using classical methods and an image analysis system. Int Rev Gesamten Hydrobiol. Hydrogr., 75 (6): 745 - 754.

PIRIA, M., D. MILOŠEVIĆ, N. ŠPREM, D. MRDAK, T. TOMLJANOVIĆ, D. MATULIĆ \& T. TREER. 2016. Condition of European eel from the Adriatic basin of Croatia and Montenegro. $51^{\text {st }}$ Croatian and $11^{\text {th }}$ International Symposium on Agriculture, February 15 - 18, 2016 Opatija, Croatia, Proceedings, 270-273.

POOLE, W., J. REYNOLDS \& C. MORIARTY. 2004. Early post-larval growth nd otolith patterns in the eel Anguilla anguilla. Fisheries Research 66, (1), 107-114.

ROSI, R. \& P. VILLANI. 1980. A biological analysis of eel catches Anguilla anguilla L., from the lagoons of Lesina and Varano, Italy. J. Fish. Biol., 16: 413-423.

TESCH, F. W. 2003. The Eel. Fifth edition. Blackwell, Oxford, UK, 408 pp.

VOLLESTAD, L. A. \& B. JONSSON. 1986. Lifehistory characteristics of the European eel Anguilla anguilla in the Imsa River, Norway. Trans. Amer. Fish. Soc., 115: 864-871.

WIRTH, T. \& L. BERNATCHES. 2001. Genetic evidence against panmixia in European eel. Nature, 409: 1037-1040.

YALÇIN-ÖZDILEK, Ş. \& K. SOLAK. 2007. The feeding of European eel (Anguilla anguilla L.) in the River Asi, Turkey. Electronic Journal of Ichthyology, pp. 26 - 35.

YALÇIN-ÖZDILEK, Ş., A. GÜMÜS \& W. DEKKER. 2006. Growth of European eel (Anguilla anguilla L.) in Turkish River at the southeastern limit of its distribution. Electronic Journal of Ichthyology, pp. 55-64.

YILMAZ, S., O. YAZICIOGLU, S.A. SAYGIN, \& N. POLAT. 2014. Relationships of Otolith Dimen- 
sions with Body Length of European Perch, Perca fluviatilis L., 1758 From Lake Ladik, Turkey; Department of Biology, Faculty of Arts and Sciences, Ondokuz Mayis Univer- sity, 55139, Kurupelit, Samsun,Turkey; Pakistan J. Zool., vol. 46(5): 1231-1238,

ZAR, J.H. 1999. Biostatistical analysis. New Jersey, Prentice - Hall., P. 469.

Received: 7 March 2017

Accepted: 10 November 2017

\title{
Odnosi dimenzija otolita s dužinom tijela kod europske jegulje Anguilla anguilla (Linnaeus, 1758) iz jadranskog sliva Crne Gore
}

\author{
Tamara KANJUH, Danilo MRDAK, Marina PIRIA, Tea TOMLJANOVIĆ \\ Aleksandar JOKSIMOVIĆ, Trajče TALEVSKI i Dragana MILOŠEVIĆ* \\ *e-pošta:draganam25@gmail.com
}

\begin{abstract}
SAŽETAK
U ovom radu se opisuje odnos između morfometrijskih varijabli sagitalnog otolita (duljina, visina i težina) i rasta tijela europske jegulje. Proučavane jegulje imale su raspon ukupne dužine od 11,2 do $79,5 \mathrm{~cm}$. Odnos između sagitalnih otolitskih varijabli i somatskog rasta ribe opisani su nelinearnom funkcijom. Dobiveni koeficijenti određivanja $\left(\mathrm{r}^{2}\right)$ kretali su se od 0,782 do 0,914. Varijabla koja je najsnažnije povezana s veličinom riba utvrđena je na temelju sagitalne duljine otolita (OL) s 91,4\% varijabilnosti. Rezultati ove studije pružaju prve sveobuhvatne podatke o odnosu između morfometrijskih varijabli sagitalnog otolita sa dužinom tijela Anguilla anguilla.
\end{abstract}

Ključne riječi: Anguilla anguilla, Jadransko more, rijeka Bojana, morfometrija otolita, somatski rast 